\title{
Leczenie pomalidomidem chorego na szpiczaka plazmocytowego po przeszczepieniu allogenicznych krwiotwórczych komórek macierzystych od dawcy niespokrewnionego
}

\author{
Pomalidomide treatment in plasma cell myeloma patient after \\ unrelated donor allogeneic hematopoietic stem cell transplantation
}

\author{
Kazimierz Hałaburda
}

Klinika Transplantacji Komórek Krwiotwórczych, Instytut Hematologii i Transfuzjologii, Warszawa

\begin{abstract}
Streszczenie
Przedstawiono opis przypadku pacjenta z rozpoznaniem szpiczaka plazmocytowego IgA kappa, którego leczono kolejno chemioterapia, bortezomibem, przeszczepieniem autologicznych krwiotwórczych komórek macierzystych, lenalidomidem, przeszczepieniem allogenicznych krwiotwórczych komórek macierzystych od dawcy niespokrewnionego oraz pomalidomidem (POM). Mimo nieuzyskania trwatej odpowiedzi postepowanie terapeutyczne, ztożone z wszystkich dostepnych $w$ Polsce metod leczenia, pozwolito na uzyskanie wieloletniego przeżycia chorego. W szczególności należy podkreślić korzystny efekt $i$ skuteczność wielomiesięcznej terapii POM, stosowanej w 6. linii leczenia.
\end{abstract}

Słowa kluczowe: szpiczak plazmocytowy, leczenie, pomalidomid

Hematologia 2017; 8, supl. A: A4-A6

\section{Abstract}

The case report presents IgA plasma cell myeloma patient treated with chemotherapy, botrezomib, autologous hematopoietic stem cell transplantation, lenalidomide, unrelated donor allogeneic hematopoietic stem cell transplantation and finally pomalidomide (POM). In spite of lack of deep, long-term response after any of the therapies, the combined treatment using all modalities currently available in Poland led to prolonged survival of the patient. Of note, POM employed as sixth-line therapy showed good efficacy and relatively few side effects over a 27-cycle treatment period.

Key words: plasma cell myeloma, treatment, pomalidomid

Hematologia 2017; 8, supl. A: A4-A6

\section{Wprowadzenie}

Standard leczenia $u$ chorych $z$ rozpoznaniem szpiczaka plazmocytowego (PCM, plasma cell myeloma) został dość dobrze określony [1]. Powszechnie uznaje się zasadność przeszczepienia autologicznych krwiotwórczych komórek macierzystych (auto-HSCT, autologous hematopoietic stem cell transplantation) $\mathrm{u}$ wszystkich chorych poniżej 70. roku życia, którzy odpowiadają na leczenie indukujące [2]. Według obecnie szeroko akceptowanych zasad chorzy po przeszczepieniu własnych komórek krwiotwórczych powinni kontynuować leczenie podtrzymujące, co wydłuża czas do progresji choroby, a według niektórych danych także czas przeżycia [3]. Przeszczepienie allogenicznych 
krwiotwórczych komórek macierzystych (allo-HSCT, allogeneic hematopoietic stem cell transplantation) w PCM powinno być przeprowadzane raczej w ramach badań klinicznych. Dzięki wprowadzeniu w ostatnich latach do badań i praktyki klinicznej nowych terapii można obserwować rosnącą skuteczność leczenia. Jednym $z$ leków wykazujących aktywność u chorych, którzy otrzymali wcześniej wiele linii leczenia, jest pomalidomid (POM).

\section{Opis przypadku}

Chorego w wieku 44 lat diagnozowano od kwietnia 2011 roku z powodu dolegliwości bólowych kręgosłupa. W ciągu 5 miesięcy poprzedzających rozpoznanie chory stracił na wadze 14 kilogramów. Po badaniach obrazowych (tomografia komputerowa [CT, computed tomography] jamy brzusznej oraz rezonans magnetyczny [MRI, magnetic resonance imaging] kręgosłupa lędźwiowego) podejrzewano nowotwór okrężnicy z przerzutami do węzłów chłonnych i kręgów. $Z$ tego powodu w lipcu 2011 roku wykonano laparotomię zwiadowczą, nie potwierdzając wcześniejszego podejrzenia. W sierpniu 2011 roku chorego skierowano na oddział ortopedyczny, gdzie usunięto większą część uwidocznionego w badaniu MRI guza kręgosłupa i przeprowadzono stabilizację transpedikularną na odcinku Th11-L3. Na podstawie badania histopatologicznego wycinków nacieku obejmującego łuki, wyrostki poprzeczne kręgu L1 oraz wpuklającego się do kanału kręgowego rozpoznano PCM. Chorego skierowano do Instytutu Hematologii i Transfuzjologii w celu uzupełnienia diagnostyki i leczenia.

Przy przyjęciu chory był leżący, z bardzo nasilonymi dolegliwościami bólowymi kręgosłupa niepozwalającymi na poruszanie się nawet $z$ asystą, podsypiający z zawrotami głowy oraz objawami częściowego porażenia czuciowego kończyn dolnych. Stwierdzano głęboką niedokrwistość normocytową (hemoglobina $86 \mathrm{~g} / \mathrm{l}$ ) oraz niewydolność nerek (kreatynina $2,48 \mathrm{mg} / \mathrm{dl}$ ) i hiperkalcemię (wapń 3,68 mmol/l). W immunofiksacji w surowicy wykryto białko monoklonalne (b.m.) IgA kappa w stężeniu 50,1 g/l. W badaniach obrazowych kośćca (radiologicznych [RTG]) uwidoczniono liczne, rozsiane zmiany osteolityczne w kościach płaskich i lewej kości udowej. Ze względu na unieruchomienie i stan ogólny chorego nie wykonano trepanobiopsji; w biopsji aspiracyjnej szpiku stwierdzono $17 \%$ plazmocytów. Zaawansowanie choroby określono na IIIB według Durie-Salmona. Rozpoczęto chemioterapię według schematu VAD (winkrystyna, doksorubicyna, deksametazon) i leczenie wspoma- gające. Po 14 dniach leczenia szpitalnego chorego wypisano do domu w dobrym stanie ogólnym.

W 1 . linii leczenia zastosowano 3 cykle chemioterapii według schematu VAD, po których u chorego wystąpiły nowe dolegliwości bólowe w obrębie żeber. W badaniach RTG stwierdzono nowe ogniska osteolityczne oraz złamania patologiczne żeber. Na tej podstawie zmieniono leczenie na terapię 2. linii i włączono chorego do programu lekowego $z$ bortezomibem. Od grudnia 2011 roku do końca maja 2012 roku chory otrzymał 8 cykli chemioterapii według schematu PAD (bortezomib, doksorubicyna, deksametazon). W wyniku leczenia osiągnięto częściową remisję choroby zasadniczej. Stwierdzano odsetek plazmocytów w szpiku wynoszący 5-7\% oraz stężenie b.m. IgA w elektroforezie białek surowicy $13 \mathrm{~g} / \mathrm{l}$.

W sierpniu 2012 roku przeprowadzono mobilizację i kolekcję komórek krwiotwórczych do auto-HSCT, które wykonano w listopadzie 2012 roku po standardowym kondycjonowaniu melfalanem w dawce $200 \mathrm{mg} / \mathrm{m}^{2}$. Zarówno w czasie przed auto-HSCT, jak i 3 miesiące po niej wykrywano stabilne stężenie b.m. w surowicy, wynoszące 7,6 g/l. Po 8 miesiącach od auto-HSCT, w lipcu 2013 roku, rozpoznano u chorego progresję choroby podstawowej, ze wzrostem stężenia b.m. do 15,6 g/l. Pacjenta włączono do programu lekowego $z$ lenalidomidem (LEN). Leczenie według schematu LEN-Dex (LEN, deksametazon) rozpoczęto 23 lipca 2013 roku. $Z$ powodu cukrzycy i trudności w kontroli glikemii stosowano terapię ze zmniejszoną dawką Dex, a następnie chory był leczony jedynie LEN. Najlepszą odpowiedź na leczenie osiągnięto w grudniu 2013 roku. W ocenie biochemicznej stężenie b.m. wynosiło wówczas $7,6 \mathrm{~g} / 1$, a odsetek plazmocytów w szpiku kostnym około 15\%. Łącznie zastosowano 12 cykli leczenia. Ze względu na młody wiek, wczesny nawrót po auto-HSCT, dobry stan ogólny oraz wyczerpanie możliwości standardowego leczenia chorego zakwalifikowano do allo-HSCT. $Z$ powodu braku zgodnego dawcy rodzinnego rozpoczęto poszukiwania dawcy niespokrewnionego.

Przeszczepienie od w pełni zgodnego dawcy, po kondycjonowaniu niemieloablacyjnym, złożonym $z$ melfalanu, fludarabiny i globuliny antylimfocytowej, przeprowadzono 22 czerwca 2014 roku. Przed rozpoczęciem kondycjonowania oceniono zaawansowanie choroby zasadniczej, stwierdzając progresję (wzrost stężenia b.m. w surowicy do $18 \mathrm{~g} / \mathrm{l}, 40 \%$ plazmocytów w trepanobiopsji). Po transplantacji nie obserwowano istotnych powikłań i chorego wypisano do domu w 25. dobie po 
przeszczepieniu w dobrym stanie ogólnym. Początkowo stwierdzano redukcję ilości białka monoklonalnego w surowicy do $5 \mathrm{~g} / \mathrm{l}$. Ze względu na ryzyko związane $z$ chorobą zasadniczą oraz brak cech choroby przeszczep przeciwko gospodarzowi leczenie immunosupresyjne ograniczano, począwszy od 60 . doby po transplantacji i wstrzymano w dobie 85. Jednak już 6 miesięcy po przeszczepieniu (12.2014 r.) stężenie b.m. oraz odsetek plazmocytów w szpiku osiągnęly wartości sprzed transplantacji.

W styczniu 2015 roku roku chory rozpoczął leczenie POM w dawce $4 \mathrm{mg} /$ dobę przez $21 \mathrm{dni}$ w cyklach 28 -dniowych. Ze względu na cukrzycę i trudną do opanowania hiperglikemię, sięgającą nawet $500 \mathrm{mg} / \mathrm{dl}$ przy dawce Dex $20 \mathrm{mg}$, pacjent otrzymuje dawki leku zmniejszone do $5-10 \mathrm{mg}$ tygodniowo. Równolegle przyjmuje kwas acetylosalicylowy w dawce $75 \mathrm{mg} /$ dobę, by obniżyć ryzyko powikłań zakrzepowo-zatorowych związanych ze stosowaniem POM. Dotychczas chory otrzymał 27 cykli leczenia. W trakcie terapii nie obserwowano istotnych powikłań hematologicznych zmuszających do modyfikacji dawki leku. Trzykrotnie stwierdzano natomiast powikłania infekcyjne dotyczące układu oddechowego, w tym raz zapalenie pluc wymagające leczenia $\mathrm{w}$ szpitalu. $Z$ powodu utrzymującej się duszności po jednej $z$ infekcji wykonano także CT klatki piersiowej, by wykluczyć zmiany śródmiąższowe płuc - obraz RTG był prawidłowy i objawy ustąpiły po krótkotrwałym leczeniu glikokortykosteroidami wziewnymi. Ponadto u pacjenta występują nawracające, znacznie częstsze niż w przeszłości, epizody opryszczki wargowej. Zmiany szybko ustępują po leczeniu acyklowirem. Obraz kliniczny i badania laboratoryjne wskazują na kontrolę choroby w okresie leczenia POM po transplantacji. Stężenie b.m. utrzymuje się na podobnym poziomie i $\mathrm{w}$ comiesięcznych badaniach waha się w granicach $14-17 \mathrm{~g} / \mathrm{l}$. W badaniu histopatologicznym szpiku kostnego nadal stwierdza się obecność 10-20\% plazmocytów. Co interesujące, powtarzane oznaczenia chimeryzmu potransplantacyjnego metodą krótkich powtórzeń tandemowych (STR, short tandem repeats) w komórkach jednojądrzastych krwi obwodowej ujaw- niają utrzymywanie się $100 \%$ chimeryzmu dawcy w czasie od 100. doby po transplantacji. W ostatnich 3 miesiącach obserwuje się jednak wyraźny wzrost stężenia b.m. w surowicy (z 15,8 g/l do 18,2 g/l), co najprawdopodobniej wynika $z$ utraty wrażliwości na stosowane leczenie immunomodulujące i zapowiada progresję. Podobnie wzrost stosunku wolnych łańcuchów kappa do lambda w surowicy wskazuje na rosnącą aktywność choroby zasadniczej. Mimo to dotychczas nie obserwuje się u pacjenta objawów klinicznych sugerujących postęp choroby, a badania biochemiczne i morfologia krwi pozostają w normie.

\section{Podsumowanie}

Przedstawiony przebieg choroby $\mathrm{u}$ młodego pacjenta $z$ rozpoznaniem PCM to przykład skutecznego przedłużania życia chorego mimo nieuzyskania całkowitej remisji czy nawet długotrwałej, głębokiej odpowiedzi. Ilustruje ograniczoną skuteczność przeszczepienia własnych komórek krwiotwórczych oraz allo-HSCT u niektórych chorych. Postępowanie terapeutyczne u tego pacjenta, odbiegające od aktualnie obowiązujących zaleceń, stanowi wypadkową dostępności leków oraz zmieniających się w czasie standardów leczenia. $\mathrm{Na}$ uwagę zasługuje skuteczność wielomiesięcznego leczenia POM zastosowanego w 6. linii terapii, po wyczerpaniu praktycznie wszystkich innych dostępnych metod leczenia. Co bardzo ważne, $\mathrm{w}$ trakcie stosowania tego leku nie obserwowano istotnych działań niepożądanych.

\section{Piśmiennictwo}

1. Plasma Cell Neoplasms (Including Multiple Myeloma) Treatment $\left(\mathrm{PDQ}^{\circledR}\right)$ : Health Professional Version. PDQ Cancer Information Summaries [Internet]. Bethesda (MD): National Cancer Institute (US); 2002-2017 Feb 3.

2. Sureda A., Bader P., Cesaro S. i wsp. Indications for allo- and auto-SCT for haematological diseases, solid tumors and immune disorders: current practice in Europe, 2015. Bone Marrow Transplant. 2015; 50: 1037-1056.

3. McCarthy P.L., Owzar K., Hofmeister C.C. i wsp. Lenalidomide after stem-cell transplantation for multiple myeloma. N. Engl. J. Med. 2012; 366: 1770-1781. 